\title{
Penandaan Batas Areal Perhutanan Sosial Dengan Pendekatan Partisipatif Pada Desa Ilanbatu Uru Kabupaten Luwu
}

\author{
Amiruddin Akbar Fisu' ${ }^{1}$ dan Didiharyono \\ ${ }^{1}$ Email: amiruddinakbarfisu07@gmail.com \\ Universitas Andi Djemma \\ 2Email: muh.didih@gmail.com \\ Universitas Andi Djemma
}

\begin{abstract}
Abstrak. Para masyarakat yang tergabung dalam kelompok perhutanan di Desa Ilanbatu Uru memiliki masalah terhadap lahan yang mereka kelola pada saat ini. Tidak adanya batas spasial yang jelas antara Kawasan hutan dan wilayah perhutanan social yang dapat mereka kelola membuat petani mengekspansi hutan karena ketidaktahuan mereka. Maksud kegiatan Penadaan Batas Areal Kerja HPHD Ilanbatu Uru adalah membantu masyarakat untuk memberikan batas-batas fisik berupa plat batas pada areal kerja HPHD sesuai dengan SK Penetapannya serta mensosialisasikan/ mengumumkan batas-batas dimaksud kepada masyarakat. Sedangkan tujuannya adalah dalam rangka terwujudnya kepastian hukum mengenai status, batas, luas dan letak wilayah areal kelola. Metode yang digunakan pada kegiatan ini yaitu menggunakan pendekatan partisipatif dan kolaboratif antara masyarakat, pemerintah dan perguruan tinggi. Dengan pelaksanaan kegiatan ini, dapat menumbuhkan kesadaran masyarakat akan Batasan wilayah kelola, sehingga masyarakat dapat diberikan kepercayaan dalam memanfaatkan potensi yang ada mulai dari pengidentifikasian masalah, menilai, dan memformulasikan permasalahannya. Dengan kegiatan ini pula dapat meminimalisir pembalakan liar pada wilayah hutan lindung di Desa Ilanbatu Uru Kabupaten Luwu.
\end{abstract}

Kata Kunci: Perhutanan sosial, pemetaan partisipatif.

\section{PENDAHULUAN}

Penyelenggaraan perhutanan sosial menjadi tanggung jawab pemerintah selaku pengelola negara yang dalam hal ini diwakili Direktorat Jenderal Perhutanan Sosial dan Kemitraan Lingkungan dibantu oleh Unit Pelaksana Teknis (UPT) Balai Perhutanan Sosial dan Kemitraan Lingkungan, sesuai dengan Peraturan Menteri Lingkungan Hidup dan Kehutanan Nomor: P.14/Menlhk /Setjen/OTL.O/I/2016. Balai Perhutanan Sosial dan Kemitraan Lingkungan mempunyai tugas melaksanakan kegiatan penyiapan kawasan perhutanan sosial, pengembangan usaha dan kemitraan serta pemetaan konflik di bidang perhutanan sosial dan kemitraan lingkungan.

Rangkaian kegiatan yang dilaksanakan oleh Balai Perhutanan Sosial dan kemitraan Lingkungan merupakan penjabaran dari RPJM Nasional Tahun 2015-2019 serta Renstra Ditjen Perhutanan Sosial dan Kemitraan Lingkungan Tahun 2015-2019 yang dituangkan dalam target kinerja. Adapun target kinerja Ditjen PSKL meningkatnya akses pengelolaan hutan oleh masyarakat, meningkatnya upaya penyelesaian konflik dan tenurial di kawasan hutan dan meningkatnya perilaku peduli lingkungan dan kehutanan. Untuk itu pemerintah telah men-targetkan alokasi kawasan hutan seluas 12,7 juta ha untuk dikelola masyarakat, 
melalui skema Hutan Kemasyarakatan (HKm), Hutan Desa (HD), Hutan Tanaman Rakyat (HTR) dan Kemitraan Kehutanan.

Sebagaimana diamanatkan dalam Peraturan Menteri Lingkungan Hidup dan Kehutanan Nomor : P. 83/MENLHK/SETJEN/KUM.1/10/2016 tentang Perhutanan Sosial bahwa salah satu kewajiban bagi pemegang HPHD, IUPHKm dan IUPHHK-HTR adalah memberi tanda batas areal kerjanya. Dalam pelaksanaan pemenuhan kewajiban tersebut dapat dibantu oleh Kelompok Kerja Percepatan Perhutanan Sosial (POKJA PPS) atau pihak lain yang tidak mengikat. Namun dalam hal areal ijin perhutanan sosial berada pada batas luar atau batas fungsi kawasan pemberian tanda batas dilaksanakan oleh UPT yang membidangi pemantapan kawasan hutan (Balai Pemantapan Kawasan Hutan).

Dalam rangka pelaksanaan perhutanan sosial di lapangan supaya program tercapai dengan aman dan tepat sasaran, maka pemerintah pusat dan pemerintah daerah melakukan kegiatan fasilitasi berupa fasilitasi pada tahap usulan permohonan, penguatan kelembagaan, peningkatan kapasitas termasuk manajemen usaha, pembentukan koperasi, tata batas areal kerja, penyusunan rencana pengelolaan hutan desa, rencana kerja usaha dan rencana kerja tahunan, bentuk-bentuk kegiatan kemitraan kehutanan, pembiayaan, pasca panen, pengembangan usaha dan akses pasar.

Penataan batas luar dan fungsi kawasan hutan yang dilaksanakan oleh Balai Pemantapan Kawasan Hutan berdasarkan Permenhut Nomor : P. 44/Menhut-II/2012 tentang Pengukuhan Kawasan Hutan dan secara teknis diatur dalam Perdirjen Planologi Kehutanan dan Tata Lingkungan Nomor : P. 3/PKTL/SEKDIT/PLA.2/9/2016 tentang Petunjuk Teknis Pengukuhan Kawasan Hutan. Namun terkait batas areal sendiri (bukan batas luar maupun batas fungsi) belum ada aturan yang mengatur pelaksanaannya.

Terkait pemenuhan kewajiban pemberian tanda batas bagi pemegang HD, HKm dan HTR, dalam hal ini batas sendiri, sesuai dengan Perdirjen PSKL Nomor : P. 16/PSKL/SET/PSL.0/11/2016 tentang Pedoman Penyusunan RPHD, RKU-IUPHKm dan RKU-IUPHHKHTR dijelaskan bahwa penandaan batas areal HKm, HD dan HTR dilakukan dengan alat ukur kompas, meteran atau Global Positioning System (GPS) dengan tanda batas yang mudah di dapat dan dikenali dilapangan. Metode pelaksanaan teknis penataan batas dengan menggunakan GPS merupakan metode penentuan posisi yang relatif mudah dengan ketelitian yang relatif tinggi serta mengacu pada suatu sistem referensi global.

\section{METODE}

Metode yang digunakan pada kegiatan ini yaitu menggunakan pendekatan partisipatif dan kolaboratif dengan melibatkan masyarakat dan kelompok tani, polisi hutan, pemerintah desa, Kementerian Kehutanan dan kami sebagai akademisi dalam proses pemetaan penandaan tapal batas perhutanan sosial. Kegiatan partisipatif diyakini dapat menambah pemahaman warga tentang urgensi wilayah kehutanan ini amat penting, sehingga masyarakatlah yang seharusnya diberikan kepercayaan dalam melaksanakan kegiatan ini, sementara kami memfasilitasi, membantu dan memberi pengarahan kepada masyarakat. 
Pendekatan partisipatif seharusnya dengan melibatkan seluruh masyarkat dalam proses pemecahan masalah (Fisu dan Marzaman, 2018). Pentingnya metode partisipatif secara berkelanjutan agar dapat berbagi informasi untuk meningkatkan kemampuan masyarakat dalam memperbaikan kehidupannya (Asnuddin, 2010). Pemahaman warga akan masalah dan potensi yang mereka miliki amat penting, sehingga masyarakatlah yang seharusnya diberikan kepercayaan dalam menyelesaikan masalah dan memanfaatkan potensi yang ada (Marzaman dkk, 2019).

\section{PEMBAHASAN}

\section{Pelaksanaan Kegiatan}

Sebelum melaksanakan kegiatan tata batas, terlebih dahulu dilakukan FGD pada Kantor Desa Ilanbatu Uru dengan membicarakan persiapan peralatan terutama kelayakan alat ukur maupun alat pendukung lainnya. Adapun hal-hal yang perlu dipersiapkan sebelum pelaksanaan kegiatan adalah persiapan alat dan bahan sebagai berikut :

a. Peta Kerja dan Pedoman Tata Batas;

b. Surat-surat yang diperssiapkan meliputi Surat Perintah Tugas (SPT), Surat Pengantar, Surat Permintaan Bantuan Tenaga dan lain-lain;

c. Alat tulis menulis, camping unit, obat-obatan dan bahan/alat lainnya yang diperlukan di lapangan;

d. Receiver GPS beserta pelengkapannya;

e. Koordinasi dengan BPKH dan dinas kehutanan lokasi penataan batas;

f. Pertemuan dengan kelompok dan Pemerintah desa tentang informasi awal lokasi dan batas-batas areal ijin perhutanan sosial serta batas utuk masing-masing kelompok dalam areal ijin.
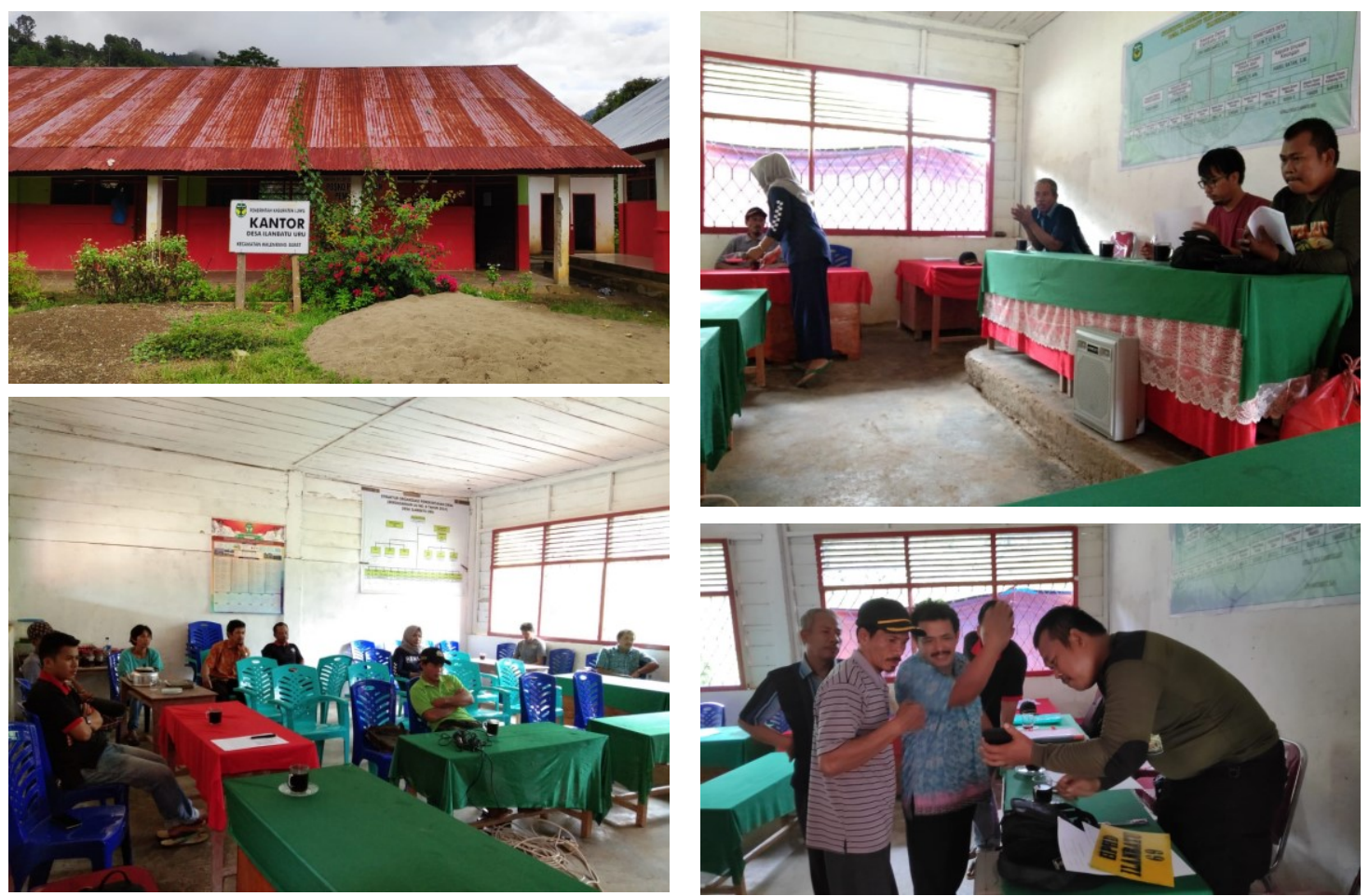

Gambar 1. Pelaksanaan FGD

To Maega, 2(2), Agustus 2019 | 3 
Tim pelaksana terdiri dari pelaksana sebanyak tiga orang yang merupakan kelompok tani dan masyarakat pengelola perhutanan social dan juga personil dari pemegang hak pengelolaan atau Izin Usaha Pemanfaatan atau Pemohon Perhutanan Sosial. Pelaksana ini memiliki tugas menyusun perencanaan pembuatan peta kerja penandaan batas; melaksanakan penandaan batas di lapangan sesuai dengan peta kerja dan ketentuan teknis pengukuran dan pemetaan; membuat laporan, berita acara dan peta hasil penandaan batas areal kerja; dan menandatangani laporan kegiatan, berita acara dan peta penandaan batas areal kerja.

Tim pelaksana berikutnya merupakan pendamping yaitu personil yang memiliki kompetensi pemetaan wilayah yang berasal dari Lembaga Sosial Masyarakat (LSM), Penyuluh, Perguruan Tinggi atau petugas yang ditunjukoleh Kepala Balai, dengan tugas membantu menyusun perencanaan dan pembuatan peta kerja penandaan batas; melakukan bimbingan teknis pelaksanaan penandaan batas di lapangan; membimbing dan membantu penyusunan laporan dan peta hasil penandaan batas sesuai kaidah-kaidah dan peraturan di bidang kehutanan; dan menandatangani berita acara dan peta penandaan batas areal kerja.

Selain itu juga terdapat saksi-saksi yaitu personil yang berasal dari Desa dan Kecamatan serta disarankan juga melibatkan saksi dari tokoh/pemuka masyarakatdan petugas dari KPH, dengan tugas memberikan kesaksian bahwa pelaksanaan penandaan batas telah dilaksanakan dengan benar dan secara partisipatif melibatkan unsur-unsur masyarakat yang terkait; ikut menyaksikan proses pelaksanaan penandaan batas di lapangan; dan juga menandatangani laporan kegiatan, berita acara dan peta penandaan batas areal kerja.

Pekerjaan lapangan dimulai dengan membuat rintis batas. Pembuatan rintis batas adalah pekerjaan menebas semak belukar ke arah dalam areal kelola, dengan lebar rintis batas yang dibuat \pm 1 (satu) meter dan tampak jelas di lapangan, sehingga dapat digunakan sebagai jalan inspeksi/pemeriksaan dan keperluan pengamanan batas hutan. Adapun teknis pelaksanaan tanda batas seperti yang diuraikan di bawah ini:

\section{a) Plat batas.}

1) Pemasangan plat batas dilaksanakan pada areal kelola ijin Perhutanan Sosial (HKm/HD/HTR) yang merupakan tata batas sendiri (bukan tata batas luar atau tata batas fungsi).

2) Pemasangan plat batas dipasang pada titik-titik ukur sesuai dengan yang direncanakan pada peta kerja sepanjang trayek batas areal kelola dengan jarak antar pal adalah \pm 100 meter dan diusahakan pada tempat yang strategis atau di titik belok batas areal kerja.

3) Plat batas areal kelola terbuat dari plat seng dengan ukuran $30 \mathrm{~cm} \mathrm{x} 20 \mathrm{~cm}$ berwarna kuning dengan tulisan berwarna hitam, kemudian dipasang pada patok kayu (gambar terlampir).

\section{b) Penomoran Plat batas}

1) Plat seng dipasang menghadap keluar areal kelola Perhutanan Sosial (HKm/HD/HTR).

2) Plat seng dituliskan huruf singkatan sesuai pola perhutanan sosial yang bersangkutan dan ditambahkan nama kelompok. 
Misalnya : HD (= Hutan Desa), HKm ( = Hutan Kemasyarakatan), HTR (= Hutan Tanaman Rakyat) + Rimba Lestari (Nama Kelompok).

3) Pemberian nomor dilakukan secara berurut mulai dari angka 1 searah putaran jarum jam pada batas areal kerja yang ditata batas.

c) Pengukuran Batas

1) Pengukuran batas dilakukan dengan menggunakan GPS dan didukung dengan kompas.

2) Sebelum kegiatan pengukuran batas dilaksanakan, terlebih dahulu dilakukan kalibrasi GPS, yaitu :

- Kalibrasi dilakukan untuk menyesuaikan dengan kondisi lokasi yang baru.

- Kalibrasi dilakukan terhadap Kompas GPS dan Altimeter GPS.

3) Penentuan titik ikat di lapangan dilakukan dengan pengambilan koordinat titik pasti/ titik kontrol/ titik markant sesuai dengan peta kerja.

4) Penentuan titik awal dilakukan dengan pengukuran garis ikatan dengan sistem navigasi sesuai azimuth dan jarak pada peta kerja/instruksi kerja.

5) Pengukuran batas areal kerja dilakukan dengan pengambilan koordinat pada setiap titik ukur dengan jarak \pm 100 meter dan pada setiap tanda batas (plat batas).
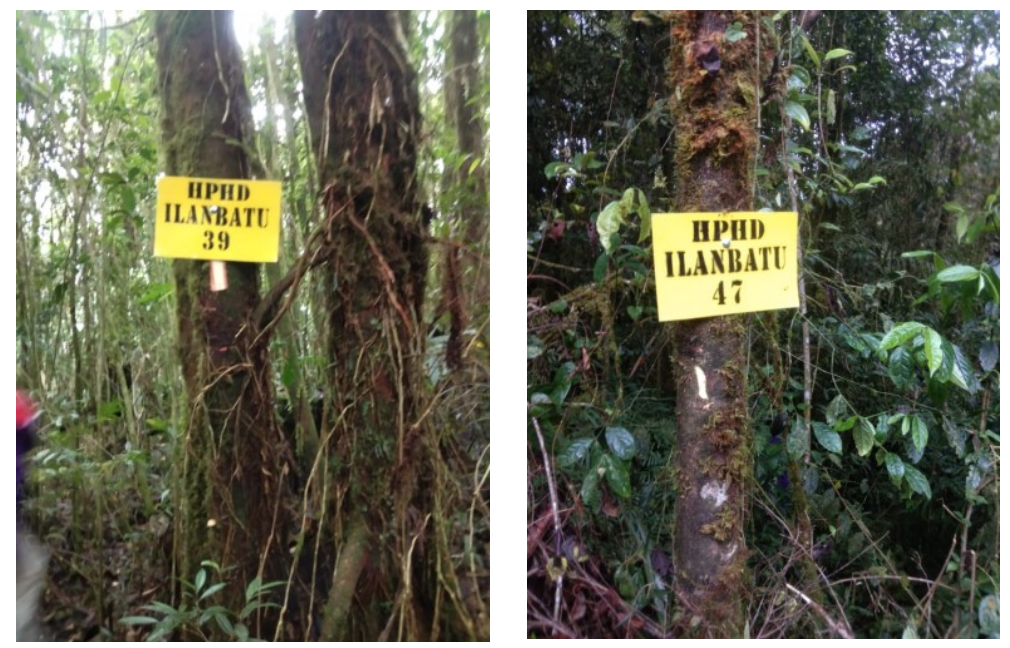

Gambar 2. Pelat Batas
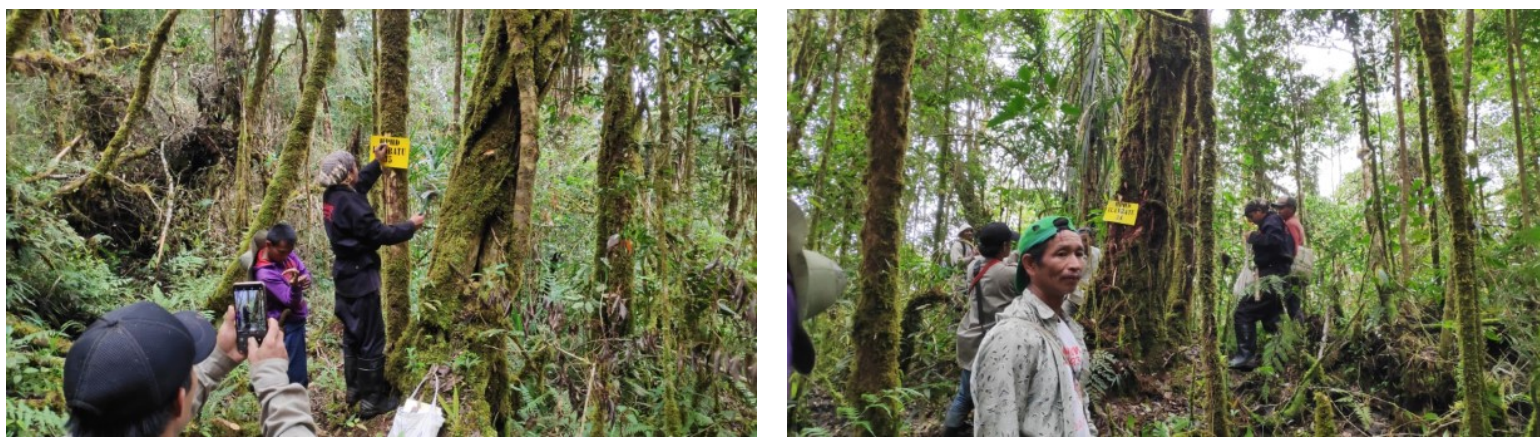

Gambar 3. Pelaksanaan Penandaan Pelat batas 


\section{Pembuatan Peta}

Hasil dari download data GPS yang menggunakan metode differential positioning dituangkan ke dalam peta hasil tata batas areal kerja sebagai lampiran Berita Acara Tata Batas. Peta hasil tata batas tersebut dilengkapi dengan layer sungai, jalan, garis pantai, garis kontur dan informasi lainnya yang bersumber dari Peta Rupa Bumi Indonesia skala terbesar yang tersedia di lokasi kawasan hutan yang ditata batas. Data/peta dasar pada wilayah tata batas dipetakan secara utuh, tidak hanya potongan garis di sekitar trayek batas. Pada Berita Acara Tata Batas untuk uraian pengukuran batas areal kerja dengan mencantumkan nomor tanda batas, koordinat dan jarak.

\section{Hasil Pelaksanaan}

Berdasarkan pelaksanaan kegiatan Penandaan Batas Areal Kerja HPHD Ilanbatu Uru yang dituangkan dalam Beriata Acara (BA) Penandaan Batas Sederhana HPHD Ilanbatu Uru dan peta sebagai lampirannya dengan hasil sebagai berikut :

1. Penandaan Batas dilaksanakan pada tanggal $15 \mathrm{~s} / \mathrm{d} 21$ Desember tahun 2018, pada wilayah Kawasan Hutan Produksi Terbatas (HPT) yang pelaksananya terdiri dari 3 (tiga) orang Pelaksana, 2 (dua) orang Pemdamping serta disaksikan oleh 2 (dua) orang saksi dari Desa.

2. Hasil pemasangan tanda batas di lapangan sesuai Peta Kerja, yaitu :

a. Dalam menentukan titik batas awal (T0) berada pada koordinat geografis menggunakan reciever GPS, yaitu pada Lintang 2॰50’03,248”S dan Bujur Timur $119^{\circ} 58^{\prime} 49,055^{\prime \prime}$ BT

b. Tedapat perubahan/ pergeseran beberapa titik awal pada lokasi penandaan batas. Hal ini dengan mempertimbangkan lokasi medan yang tidak memungkinkan untuk pengelolaan HD, serta masukan dari warga dan tokoh masyarakat setempat. Titiktitik tersebut yaitu titik 1, 2, 3, 7, 13, 15, 16, 22, 23,24, dan titik 61 dengan rentang pergeseran dari awal antara 23 meter hingga 61 meter.

c. Tititk-titik batas areal kerja setelah dilakukan pemasangan tanda batas adalah sebagaimana tabel berikut :

Tabel 1. Koordinat Hasil Penandaan Plat batas

\begin{tabular}{|c|c|c|c|c|c|c|c|}
\hline \multirow{2}{*}{$\begin{array}{c}\text { Plat } \\
\text { Batas }\end{array}$} & \multirow{2}{*}{ Trayek } & \multicolumn{2}{|c|}{ Koordinat Geografis } & \multicolumn{2}{|c|}{ Koordinat UTM } & \multirow{2}{*}{ Jarak Datar } & \multirow{2}{*}{ Pergeseran } \\
\hline & & $\mathbf{X}$ & $\mathbf{Y}$ & x_utm & y_utm & & \\
\hline 1 & Titik $1-2$ & $119^{\circ} 58^{\prime} 49,055^{\prime \prime} \mathrm{E}$ & $2^{\circ} 50^{\prime} 03,248^{\prime \prime} \mathrm{S}$ & 164252 & 9686295 & 94,16 & 23 \\
\hline 2 & Titik 2 - 3 & $119^{\circ} 58^{\prime} 47,661^{\prime \prime} \mathrm{E}$ & $2^{\circ} 50^{\prime} 00661 " \mathrm{~S}$ & 164228 & 9686387 & 99,50 & 42 \\
\hline 3 & Titik $3-4$ & $119^{\circ} 58^{\prime} 47,299^{\prime \prime} \mathrm{E}$ & $2^{\circ} 49^{\prime} 57,436^{\prime \prime} \mathrm{S}$ & 164238 & 9686486 & 94,79 & 61 \\
\hline 4 & Titik $4-5$ & $119^{\circ} 58^{\prime} 46,325^{\prime \prime} \mathrm{E}$ & $2^{\circ} 49^{\prime} 54,843^{\prime \prime} \mathrm{S}$ & 164173 & 9686555 & 97,67 & 23 \\
\hline 5 & Titik $5-6$ & $119^{\circ} 58^{\prime} 44,940^{\prime \prime} \mathrm{E}$ & $2^{\circ} 49^{\prime} 52,318^{\prime \prime} \mathrm{S}$ & 164107 & 9686627 & 100,18 & \\
\hline 6 & Titik $6-7$ & $119^{\circ} 58^{\prime} 43,477^{\prime \prime} \mathrm{E}$ & $2^{\circ} 49^{\prime} 49,437^{\prime \prime} \mathrm{S}$ & 164061 & 9686716 & 65,19 & \\
\hline 7 & Titik $7-8$ & $119^{\circ} 58^{\prime} 41,005^{\prime \prime} \mathrm{E}$ & $2^{\circ} 49^{\prime} 49,289^{\prime \prime} \mathrm{S}$ & 164018 & 9686765 & 71,09 & 56 \\
\hline
\end{tabular}


TO MAEGA Volume 2 Nomor 2, Agustus 2019, hlm : 1-10

\begin{tabular}{|c|c|c|c|c|c|c|c|}
\hline \multirow{2}{*}{$\begin{array}{l}\text { Plat } \\
\text { Batas }\end{array}$} & \multirow{2}{*}{ Trayek } & \multicolumn{2}{|c|}{ Koordinat Geografis } & \multicolumn{2}{|c|}{ Koordinat UTM } & \multirow{2}{*}{ Jarak Datar } & \multirow{2}{*}{ Pergeseran } \\
\hline & & $\mathbf{X}$ & $\mathbf{Y}$ & x_utm & y_utm & & \\
\hline 8 & Titik $8-9$ & $119^{\circ} 58^{\prime} 39,212^{\prime \prime} \mathrm{E}$ & $2^{\circ} 49^{\prime} 48,271^{\prime \prime} \mathrm{S}$ & 163929 & 9686751 & 69,01 & \\
\hline 9 & Titik $9-10$ & $119^{\circ} 58^{\prime} 36,972^{\prime \prime} \mathrm{E}$ & $2^{\circ} 49^{\prime} 45,944^{\prime \prime} \mathrm{S}$ & 163860 & 9686822 & 99,25 & \\
\hline 10 & Titik $10-11$ & $119^{\circ} 58^{\prime} 34,873^{\prime \prime} \mathrm{E}$ & $2^{\circ} 49^{\prime} 43,526^{\prime \prime} \mathrm{S}$ & 163795 & 9686897 & 98,29 & \\
\hline 11 & Titik $11-12$ & $119^{\circ} 58^{\prime} 32,631^{\prime \prime} \mathrm{E}$ & $2^{\circ} 49^{\prime} 41,281^{\prime \prime} \mathrm{S}$ & 163725 & 9686966 & 98,35 & \\
\hline 12 & Titik $12-13$ & $119^{\circ} 58^{\prime} 31,588^{\prime \prime} \mathrm{E}$ & $2^{\circ} 49^{\prime} 38,223^{\prime \prime} \mathrm{S}$ & 163693 & 9687059 & 100,28 & \\
\hline 13 & Titik $13-14$ & $119^{\circ} 58^{\prime} 30,433^{\prime \prime} \mathrm{E}$ & $2^{\circ} 49^{\prime} 35,192^{\prime \prime} \mathrm{S}$ & 163677 & 9687158 & 96,24 & 21 \\
\hline 14 & Titik $14-15$ & $119^{\circ} 58^{\prime} 30,064^{\prime \prime} \mathrm{E}$ & $2^{\circ} 49^{\prime} 31,927^{\prime \prime} \mathrm{S}$ & 163645 & 9687253 & 103,40 & \\
\hline 15 & Titik $15-16$ & $119^{\circ} 58^{\prime} 27,814^{\prime \prime} \mathrm{E}$ & $2^{\circ} 49^{\prime} 29,283^{\prime \prime} \mathrm{S}$ & 163605 & 9687344 & 97,50 & 31 \\
\hline 16 & Titik $16-17$ & $119^{\circ} 58^{\prime} 26,151^{\prime \prime} \mathrm{E}$ & $2^{\circ} 49^{\prime} 26,592^{\prime \prime} \mathrm{S}$ & 163553 & 9687430 & 91,70 & 33 \\
\hline 17 & Titik $17-18$ & $119^{\circ} 58^{\prime} 24,840^{\prime \prime} \mathrm{E}$ & $2^{\circ} 49^{\prime} 23,860^{\prime \prime} \mathrm{S}$ & 163483 & 9687501 & 99,62 & \\
\hline 18 & Titik $18-19$ & $119^{\circ} 58^{\prime} 22,975^{\prime \prime} \mathrm{E}$ & $2^{\circ} 49^{\prime} 21,207^{\prime \prime} \mathrm{S}$ & 163425 & 9687582 & 97,94 & \\
\hline 19 & Titik $19-20$ & $119^{\circ} 58^{\prime} 20,288^{\prime \prime} \mathrm{E}$ & $2^{\circ} 49^{\prime} 19,492^{\prime \prime} \mathrm{S}$ & 163342 & 9687634 & 100,44 & \\
\hline 20 & Titik $20-21$ & $119^{\circ} 58^{\prime} 18,433^{\prime \prime} \mathrm{E}$ & $2^{\circ} 49^{\prime} 16,831^{\prime \prime} \mathrm{S}$ & 163284 & 9687716 & 99,85 & \\
\hline 21 & Titik $21-22$ & $119^{\circ} 58^{\prime} 16,829^{\prime \prime} \mathrm{E}$ & $2^{\circ} 49^{\prime} 14,014^{\prime \prime} \mathrm{S}$ & 163235 & 9687803 & 99,98 & \\
\hline 22 & Titik $22-23$ & $119^{\circ} 58^{\prime} 14,397^{\prime \prime} \mathrm{E}$ & $2^{\circ} 49^{\prime} 11,492^{\prime \prime} \mathrm{S}$ & 163184 & 9687889 & 100,02 & 28 \\
\hline 23 & Titik $23-24$ & $119^{\circ} 58^{\prime} 11,817^{\prime \prime} \mathrm{E}$ & $2^{\circ} 49^{\prime} 8,923^{\prime \prime} \mathrm{S}$ & 163123 & 9687967 & 113,39 & 44 \\
\hline 24 & Titik $24-25$ & $119^{\circ} 58^{\prime} 10,372^{\prime \prime} \mathrm{E}$ & $2^{\circ} 49^{\prime} 6,635^{\prime \prime} \mathrm{S}$ & 163079 & 9688055 & 70,04 & 54 \\
\hline 25 & Titik $25-26$ & $119^{\circ} 58^{\prime} 8,700^{\prime \prime} \mathrm{E}$ & $2^{\circ} 49^{\prime} 5,149^{\prime \prime} \mathrm{S}$ & 162982 & 9688075 & 98,49 & \\
\hline 26 & Titik $26-27$ & $119^{\circ} 58^{\prime} 5,786^{\prime \prime} \mathrm{E}$ & $2^{\circ} 49^{\prime} 3,826^{\prime \prime} \mathrm{S}$ & 162892 & 9688115 & 99,25 & \\
\hline 27 & Titik $27-28$ & $119^{\circ} 58^{\prime} 3,346^{\prime \prime} \mathrm{E}$ & $2^{\circ} 49^{\prime} 1,714^{\prime \prime} \mathrm{S}$ & 162817 & 9688180 & 99,70 & \\
\hline 28 & Titik $28-29$ & $119^{\circ} 58^{\prime} 1,088^{\prime \prime} \mathrm{E}$ & $2^{\circ} 48^{\prime} 59,401 " \mathrm{~S}$ & 162747 & 9688251 & 99,62 & \\
\hline 29 & Titik $29-30$ & $119^{\circ} 57^{\prime} 58,470^{\prime \prime} \mathrm{E}$ & $2^{\circ} 48^{\prime} 57,494 " \mathrm{~S}$ & 162666 & 9688309 & 100,44 & \\
\hline 30 & Titik $30-31$ & $119^{\circ} 57^{\prime} 55,844^{\prime \prime} \mathrm{E}$ & $2^{\circ} 48^{\prime} 55,607^{\prime \prime} \mathrm{S}$ & 162584 & 9688367 & 99,30 & \\
\hline 31 & Titik $31-32$ & $119^{\circ} 57^{\prime} 52,786^{\prime \prime} \mathrm{E}$ & $2^{\circ} 48^{\prime} 54,558^{\prime \prime} \mathrm{S}$ & 162490 & 9688399 & 99,74 & \\
\hline 32 & Titik $32-33$ & $119^{\circ} 57^{\prime} 49,883^{\prime \prime} \mathrm{E}$ & $2^{\circ} 48^{\prime} 53,135^{\prime \prime} \mathrm{S}$ & 162400 & 9688442 & 84,40 & \\
\hline 33 & Titik $33-34$ & $119^{\circ} 57^{\prime} 47,687^{\prime \prime} \mathrm{E}$ & $2^{\circ} 48^{\prime} 51,528^{\prime \prime} \mathrm{S}$ & 162332 & 9688492 & 99,50 & \\
\hline 34 & Titik $34-35$ & $119^{\circ} 57^{\prime} 47,393^{\prime \prime} \mathrm{E}$ & $2^{\circ} 48^{\prime} 48,294^{\prime \prime} \mathrm{S}$ & 162322 & 9688591 & 98,67 & \\
\hline 35 & Titik $35-36$ & $119^{\circ} 57^{\prime} 46,404^{\prime \prime} \mathrm{E}$ & $2^{\circ} 48^{\prime} 45,244^{\prime \prime} \mathrm{S}$ & 162292 & 9688685 & 97,41 & \\
\hline 36 & Titik $36-37$ & $119^{\circ} 57^{\prime} 45,384^{\prime \prime} \mathrm{E}$ & $2^{\circ} 48^{\prime} 42,240^{\prime \prime} \mathrm{S}$ & 162260 & 9688777 & 100,00 & \\
\hline 37 & Titik $37-38$ & $119^{\circ} 57^{\prime} 45,409^{\prime \prime} \mathrm{E}$ & $2^{\circ} 48^{\prime} 38,993^{\prime \prime} \mathrm{S}$ & 162260 & 9688877 & 99,85 & \\
\hline 38 & Titik $38-39$ & $119^{\circ} 57^{\prime} 45,829^{\prime \prime} \mathrm{E}$ & $2^{\circ} 48^{\prime} 35,768^{\prime \prime} \mathrm{S}$ & 162273 & 9688976 & 99,85 & \\
\hline 39 & Titik $39-40$ & $119^{\circ} 57^{\prime} 46,264^{\prime \prime} \mathrm{E}$ & $2^{\circ} 48^{\prime} 32,551 " \mathrm{~S}$ & 162286 & 9689075 & 99,69 & \\
\hline 40 & Titik $40-41$ & $119^{\circ} 57^{\prime} 47,005^{\prime \prime} \mathrm{E}$ & $2^{\circ} 48^{\prime} 29,387^{\prime \prime} \mathrm{S}$ & 162309 & 9689172 & 93,64 & \\
\hline
\end{tabular}


To Maega | Jurnal Pengabdian Masyarakat

P-ISSN: 2622-6332 \& E-ISSN: 2622-6340

TOMAEGA Volume 2 Nomor 2, Agustus 2019, hlm : 1-10

\begin{tabular}{|c|c|c|c|c|c|c|c|}
\hline \multirow{2}{*}{$\begin{array}{c}\text { Plat } \\
\text { Batas }\end{array}$} & \multirow{2}{*}{ Trayek } & \multicolumn{2}{|c|}{ Koordinat Geografis } & \multicolumn{2}{|c|}{ Koordinat UTM } & \multirow{2}{*}{ Jarak Datar } & \multirow{2}{*}{ Pergeseran } \\
\hline & & $\mathbf{X}$ & $\mathbf{Y}$ & x_utm & y_utm & & \\
\hline 41 & Titik $41-42$ & $119^{\circ} 57^{\prime} 45,983 " \mathrm{E}$ & $2^{\circ} 48^{\prime} 26,549^{\prime \prime} \mathrm{S}$ & 162277 & 9689260 & 54,57 & \\
\hline 42 & Titik $42-43$ & $119^{\circ} 57^{\prime} 47,691 " \mathrm{E}$ & $2^{\circ} 48^{\prime} 26,105^{\prime \prime} \mathrm{S}$ & 162330 & 9689273 & 100,02 & \\
\hline 43 & Titik $43-44$ & $119^{\circ} 57^{\prime} 50,925^{\prime \prime} \mathrm{E}$ & $2^{\circ} 48^{\prime} 26,174^{\prime \prime} \mathrm{S}$ & 162430 & 9689271 & 100,00 & \\
\hline 44 & Titik $44-45$ & $119^{\circ} 57^{\prime} 54,159^{\prime \prime} \mathrm{E}$ & $2^{\circ} 48^{\prime} 26,243^{\prime \prime} \mathrm{S}$ & 162530 & 9689270 & 100,02 & \\
\hline 45 & Titik $45-46$ & $119^{\circ} 57^{\prime} 57,393 " \mathrm{E}$ & $2^{\circ} 48^{\prime} 26,312^{\prime \prime} \mathrm{S}$ & 162630 & 9689268 & 100,02 & \\
\hline 46 & Titik $46-47$ & $119^{\circ} 58^{\prime} 0,627^{\prime \prime} \mathrm{E}$ & $2^{\circ} 48^{\prime} 26,380^{\prime \prime} \mathrm{S}$ & 162730 & 9689266 & 100,02 & \\
\hline 47 & Titik $47-48$ & $119^{\circ} 58^{\prime} 3,862^{\prime \prime} \mathrm{E}$ & $2^{\circ} 48^{\prime} 26,449^{\prime \prime} \mathrm{S}$ & 162830 & 9689264 & 98,84 & \\
\hline 48 & Titik $48-49$ & $119^{\circ} 58^{\prime} 7,002^{\prime \prime} \mathrm{E}$ & $2^{\circ} 48^{\prime} 27,089^{\prime \prime} \mathrm{S}$ & 162927 & 9689245 & 99,62 & \\
\hline 49 & Titik $49-50$ & $119^{\circ} 58^{\prime} 10,087^{\prime \prime} \mathrm{E}$ & $2^{\circ} 48^{\prime} 28,067^{\prime \prime} \mathrm{S}$ & 163022 & 9689215 & 100,58 & \\
\hline 50 & Titik $50-51$ & $119^{\circ} 58^{\prime} 13,172^{\prime \prime} \mathrm{E}$ & $2^{\circ} 48^{\prime} 29,045^{\prime \prime} \mathrm{S}$ & 163118 & 9689185 & 100,17 & \\
\hline 51 & Titik $51-52$ & $119^{\circ} 58^{\prime} 15,909^{\prime \prime} \mathrm{E}$ & $2^{\circ} 48^{\prime} 30,772^{\prime \prime} \mathrm{S}$ & 163203 & 9689132 & 99,86 & \\
\hline 52 & Titik $52-53$ & $119^{\circ} 58^{\prime} 18,633^{\prime \prime} \mathrm{E}$ & $2^{\circ} 48^{\prime} 32,526^{\prime \prime} \mathrm{S}$ & 163287 & 9689078 & 99,32 & \\
\hline 53 & Titik $53-54$ & $119^{\circ} 58^{\prime} 21,357^{\prime \prime} \mathrm{E}$ & $2^{\circ} 48^{\prime} 34,279^{\prime \prime} \mathrm{S}$ & 163371 & 9689025 & 100,70 & \\
\hline 54 & Titik $54-55$ & $119^{\circ} 58^{\prime} 24,081^{\prime \prime} \mathrm{E}$ & $2^{\circ} 48^{\prime} 36,033^{\prime \prime} \mathrm{S}$ & 163456 & 9688971 & 99,86 & \\
\hline 55 & Titik $55-56$ & $119^{\circ} 58^{\prime} 26,805^{\prime \prime} \mathrm{E}$ & $2^{\circ} 48^{\prime} 37,787^{\prime \prime} \mathrm{S}$ & 163540 & 9688917 & 99,85 & \\
\hline 56 & Titik $56-57$ & $119^{\circ} 58^{\prime} 29,611^{\prime \prime} \mathrm{E}$ & $2^{\circ} 48^{\prime} 39,400^{\prime \prime} \mathrm{S}$ & 163627 & 9688868 & 100,65 & \\
\hline 57 & Titik $57-58$ & $119^{\circ} 58^{\prime} 32,472^{\prime \prime} \mathrm{E}$ & $2^{\circ} 48^{\prime} 40,917 " \mathrm{~S}$ & 163716 & 9688821 & 99,30 & \\
\hline 58 & Titik 58 -59 & $119^{\circ} 58^{\prime} 35,334^{\prime \prime} \mathrm{E}$ & $2^{\circ} 48^{\prime} 42,434 " \mathrm{~S}$ & 163804 & 9688775 & 100,18 & \\
\hline 59 & Titik $59-60$ & $119^{\circ} 58^{\prime} 38,195^{\prime \prime} \mathrm{E}$ & $2^{\circ} 48^{\prime} 43,951 " \mathrm{~S}$ & 163893 & 9688729 & 99,76 & \\
\hline 60 & Titik $60-61$ & $119^{\circ} 58^{\prime} 41,057^{\prime \prime} \mathrm{E}$ & $2^{\circ} 48^{\prime} 45,468^{\prime \prime} \mathrm{S}$ & 163981 & 9688682 & 100,18 & \\
\hline 61 & Titik $61-62$ & $119^{\circ} 58^{\prime} 44,800^{\prime \prime} \mathrm{E}$ & $2^{\circ} 48^{\prime} 45,907 " \mathrm{~S}$ & 164070 & 9688636 & 113,16 & 42 \\
\hline 62 & Titik $62-63$ & $119^{\circ} 58^{\prime} 46,297^{\prime \prime} \mathrm{E}$ & $2^{\circ} 48^{\prime} 49,147^{\prime \prime} \mathrm{S}$ & 164144 & 9688570 & 117,72 & \\
\hline 63 & Titik $63-64$ & $119^{\circ} 58^{\prime} 48,540^{\prime \prime} \mathrm{E}$ & $2^{\circ} 48^{\prime} 51,490^{\prime \prime} \mathrm{S}$ & 164213 & 9688498 & 100,42 & \\
\hline 64 & Titik $64-65$ & $119^{\circ} 58^{\prime} 50,784^{\prime \prime} \mathrm{E}$ & $2^{\circ} 48^{\prime} 53,833^{\prime \prime} \mathrm{S}$ & 164283 & 9688426 & 99,72 & \\
\hline 65 & Titik $65-66$ & $119^{\circ} 58^{\prime} 53,027^{\prime \prime} \mathrm{E}$ & $2^{\circ} 48^{\prime} 56,176^{\prime \prime} \mathrm{S}$ & 164352 & 9688354 & 95,13 & \\
\hline 66 & Titik $66-67$ & $119^{\circ} 58^{\prime} 53,657^{\prime \prime} \mathrm{E}$ & $2^{\circ} 48^{\prime} 59,210^{\prime \prime} \mathrm{S}$ & 164372 & 9688261 & 100,08 & \\
\hline 67 & Titik $67-68$ & $119^{\circ} 58^{\prime} 53,779^{\prime \prime} \mathrm{E}$ & $2^{\circ} 49^{\prime} 2,460^{\prime \prime} \mathrm{S}$ & 164376 & 9688161 & 100,08 & \\
\hline 68 & Titik $68-69$ & $119^{\circ} 58^{\prime} 53,902^{\prime \prime} \mathrm{E}$ & $2^{\circ} 49^{\prime} 5,710^{\prime \prime} \mathrm{S}$ & 164380 & 9688061 & 100,08 & \\
\hline 69 & Titik 69 & $119^{\circ} 58^{\prime} 54,024^{\prime \prime} \mathrm{E}$ & $2^{\circ} 49^{\prime} 8,960^{\prime \prime} \mathrm{S}$ & 164384 & 9687961 & & \\
\hline
\end{tabular}

3. Rintis batas dibuat selebar \pm 1 meter yang menghubungkan satu titik dengan titik berikutnya dengan keseluruhan panjang batas lebih kurang 6.607 meter . 
4. Titik-titik batas. Titik-titik batas berupa plat seng dengan memberikan kode inisial HPHD Ilanbatu Uru 1, HPHD Ilanbatu Uru 2, ..., dst sebanyak 69 (enam puluh sembilan) buah.

5. Batas Areal Kerja HPHD Ilanbatu Uru meliputi :

a. Sebelah Utara berbatasan dengan Desa Lempepasang dan desa lamasi Ulu

b. Sebelah Timur berbatasan dengan Dusun ponganan, Dusun Paranta, dan Dusun Bilolo

c. Sebelah Selatan berbatasan dengan Dusun Paonganan dan Dusun Bilolo

d. Sebelah Barat berbatasan dengan Dusun Tokarondang dan Dusun kampung Baru

6. Peralatan yang digunakan adalah reciever GPS merk Garmin type etrex 10

\section{SIMPULAN DAN SARAN}

Dengan melakukan penandaan tapal batas perhutanan sosial menggunakan pendekatan partisipatif yang melibatkan seluruh masyarakat dalam proses penandaan, akan menumbuhkan pemahaman dan kesadaran warga akan Batasan wilayah kelola yang boleh dikelola oleh kelompok tani dan masyarakat, sehingga masyarakatlah yang seharusnya diberikan kepercayaan dalam menyelesaikan masalah dan memanfaatkan potensi yang ada mulai dari pengidentifikasian masalah; menilai dan memformulasikan permasalahannya. Dengan kegiatan ini pula dapat meminimalisir pembalakan liar pada wilayah hutan lindung di Desa Ilanbatu Uru Kabupaten Luwu. Adapun saran yang diberikan kepada masyarakat yaitu agar bisa menjaga, melindungi, dan memanfaatkan potensi hutan dengan baik dan tidak merusak lingkungan. Marilah kita jaga dan merawat lingkungan kita, demi terciptanya lingkungan yang sehat untuk kebaikan kehidupan manusia saat sekarang dan dimasa yang akan datang.

\section{DAFTAR PUSTAKA}

Ahmad, A., Fisu, A. A., \& Didiharyono, D. (2019). Analisis Potensi Ekosistem Mangrove Sebagai Pengembangan Objek Wisata (Studi Kasus: Kabupaten Wakatobi). Prosiding, 4(1): $177-186$

Asnuddin, Andi. (2010). Pendekatan Partisipatif dalam Pembangunan Proyek Infrastruktur Perdesaan di Indonesia. Jurnal Smartek Vol.8 No.3 2010 (182 - 190)

Dani, A. A. H., \& Apriyanto, A. (2019). Penandaan Batas Area Perhutanan Sosial pada Desa Tombang Kecamatan Walenrang Kabupaten Luwu. To Maega| Jurnal Pengabdian Masyarakat, 2(1), 30-37.

Fisu, A. A., \& Marzaman, L. U. (2018). PEMETAAN PARTISIPATIF KAMPUNG PESISIR KELURAHAN TALLO KOTA MAKASSAR. To Maega| Jurnal Pengabdian Masyarakat, 1(1).

Marzaman LU, Hafid Z, Fisu AA. \& Nurhijrah. (2019). Merajut Cerita di Kota Tua (Revitalisasi Kawasan Ex Pasar Lama Palopo). https://doi.org/10.31227/osf.io/zmy4e

Muljono, P. (2009). Kinerja Aspek Sosial dalam Pengelolaan Hutan Alam Lestari: Studi Kasus pada HPH PT. Sumalindo Lestari Jaya (SLJ) II Provinsi Kalimantan Timur. Sodality: Jurnal Sosiologi Pedesaan, 3(3). 
TOMAEGA Volume 2 Nomor 2, Agustus 2019, hlm : 1-10

Peraturan Menteri Lingkungan Hidup dan Kehutanan No: P. 14/Menlhk /Setjen/OTL.O/I/2016

Peraturan Menteri Lingkungan Hidup dan Kehutanan No: P.83/MENLHK/SETJEN/KUM.1/10/2016 tentang Perhutanan Sosial

Peraturan Menteri Kehutanan No: P. 44/Menhut-II/2012 tentang Pengukuhan Kawasan Hutan

Peraturan Dirjen Planologi Kehutanan dan Tata Lingkungan No: P.3/PKTL/SEKDIT/PLA.2/9/2016 tentang Petunjuk Teknis Pengukuhan Kawasan Hutan

Peraturan Ditjen PSKL Nomor : P. 16/PSKL/SET/PSL.0/11/2016 tentang Pedoman Penyusunan RPHD, RKU-IUPHKm dan RKU-IUPHHKHTR.

Zulevi, X. F., \& Adiwibowo, S. (2018). Pengaruh Partisipasi dalam Pengelolaan Hutan Nagari Simancuang terhadap Tingkat Kesejahteraan Masyarakat. Jurnal Sains Komunikasi dan Pengembangan Masyarakat [JSKPM], 2(1), 13-28. 